\title{
Startup Branding: Empirical Evidence among Slovenian Startups
}

Matej Rus

University of Maribor, Slovenia

matej.rus@um.si

Maja Konecnik Ruzzier

University of Ljubljana, Slovenia

maja.konecnik@ef.uni-lj.si

Mitja Ruzzier

University of Primorska, Slovenia

mitja.ruzzier@fm-kp.si

Branding seems to be an important issue among all companies, also among newly established and young companies with high growth potential or socalled startups. This was also confirmed in our empirical research, conducted among 195 Slovenian startups. Startup founders/CEOs see branding as the most important business strategy in their companies. Separated startup branding building blocks were evaluated as similarly important, from brand vision and context building blocks to brand development and its implementation. These findings bring important managerial implications not only for startups, but also for other companies that want to treat and maintain their brands as dynamic and evolving entities.

Key Words: branding, startup, story, innovation

JEL Classification: M31, M39

https://doi.org/10.26493/1854-6935.16.79-94

\section{Introduction}

Examples such as Tesla, Facebook, Uber or Airbnb have shaped the anticipation that startups will be the ones to come up with the next great innovation, disrupt entire industries, and build a strong brand. According to Interbrand's evaluation of Best Global Brands in 2016, Facebook showed the highest growth among all brands (48\% in year 2015), while Tesla became a new member among 100 top valued brands (see http://interbrand.com/best-brands/best-global-brands/2016/ranking/). Previous data as well as many other examples in today's competitive environment show that branding is important among new companies as well, especially among those that have innovation ideas with growth potential. 
The times when branding was generally connected to large companies or even multinationals are over. Today's fierce environment, in combination with endless use of information and communication technologies, has significantly changed the rules in the field of branding (Konecnik Ruzzier, Ruzzier, and Hisrich 2013). Branding has become a crucial activity for the successful establishment of a new company, its long-term survival, and favourable and strong equity in the eyes of its target customers (Gardner and Cooper 2014).

The main purpose of this paper is to present the importance of branding among startups and to examine whether startups in Slovenia recognized branding activities as important activities during their development and implementation on the market. Startups founders or CEOS of 195 companies have shared their opinion about the importance of branding in their operations on the market and evaluated separate steps in the proposed startup branding funnel model.

\section{Defining Startups and Their Role in the Economy}

Although startups and their role in the economy are growing, there is no commonly accepted definition of a startup. According to Rode and Vallaster (2005), startups are raw companies, without any organizational structure, acting legally and economically in the market for a short time. Moreover, the authors explained that this type of business is regularly characterized by a strong personal influence of founders and small business networks. Ries $(2011,27)$ defied a startup as a 'human institution designed to create a new product or service under conditions of extreme uncertainty', while he omits the organization's size, industry and sector of the economy. A similar definition is proposed by Ruzzier and Ruzzier $(2015,19)$, who say that a startup is 'a team of people that works on a common goal to create something new and impactful, driven by a future vision and potential of sharp growth, sharing an exciting and passionate atmosphere, working in unstable conditions and with high risk of failure.' While Rode and Vallaster (2005) and some other authors (e.g. Timmons 1999) also relate startup characteristics with a time dimension, recent definitions (Ries 2011; Ruzzier and Ruzzier 2015) omit it and instead of the time frame stress the role of innovation, growth and unstable conditions in the marketplace.

Startups are often based on innovative ideas with growth potential, and could be the company to change the marketplace and create the uncontested market space (Weiblen and Chesbrough 2015). A startup has 
TABLE 1 Main Characteristics of IDES and Traditional SMES

\begin{tabular}{|c|c|}
\hline IDES & SMES \\
\hline Focus on global markets. & $\begin{array}{l}\text { Focus on addressing local and regional } \\
\text { markets only. }\end{array}$ \\
\hline $\begin{array}{l}\text { The company is based on some sort of } \\
\text { innovation (tech, process, business model) } \\
\text { and potential competitive advantage. }\end{array}$ & $\begin{array}{l}\text { Innovation is not necessary to SME estab- } \\
\text { lishment and growth, nor is competitive } \\
\text { advantage. }\end{array}$ \\
\hline $\begin{array}{l}\text { 'Tradable jobs' - jobs that do not have to } \\
\text { be performed locally. }\end{array}$ & $\begin{array}{l}\text { 'Non-tradable jobs' - jobs generally per- } \\
\text { formed locally, e.g. restaurants, dry clean- } \\
\text { ers, service industry. }\end{array}$ \\
\hline $\begin{array}{l}\text { More diverse ownership base including } \\
\text { wide array of external capital providers. }\end{array}$ & $\begin{array}{l}\text { Most often family businesses or businesses } \\
\text { with very little external capital. }\end{array}$ \\
\hline $\begin{array}{l}\text { The company starts by losing money, } \\
\text { but if successful will have exponential } \\
\text { growth. Requires investment. When you } \\
\text { put money into the company, the rev- } \\
\text { enue/cash flow/jobs numbers do not re- } \\
\text { spond quickly. }\end{array}$ & $\begin{array}{l}\text { The company typically grows at a linear } \\
\text { rate. When you put money into the com- } \\
\text { pany, the system (revenue, cash flow, jobs, } \\
\text { etc.) will respond quickly in a positive } \\
\text { manner. }\end{array}$ \\
\hline
\end{tabular}

notes Adapted from Aulet and Murray (2013).

promising ideas, organizational agility, the willingness to take risks, and aspirations of rapid growth (Weiblen and Chesbrough 2015). Similar was also proposed by Rus and Rebernik (2015), who stated that startups are an important driver of the development of new business ideas, innovations and technologies in the economy. They attract creative individuals, increase the level of engagement of entrepreneurial talent and contribute to the commercialization of new knowledge and technologies. In most cases, startup companies are developing globally interesting products or services, which are also intensively directed towards growth through the internationalization of their business (Rus and Rebernik 2015). Innovation, growth, risk, uncertainty, agility are all words that describe startups well. However, it is important to stress that not all new companies are startup companies.

Aulet and Murray (2013) distinguished between two types of enterprises. As the first type, they refer to 'innovation-driven enterprises' (IDES) that pursue global opportunities based on bringing to customers innovations that have a clear competitive advantage and high growth potential. IDES can be a synonym for startups. The second type refers to 'small- and medium-sized enterprises' (sMEs), which are serving local markets with traditional, well-understood business ideas and a limited 
competitive advantage. SMEs generally have low growth potential and linear growth rate, while IDEs have high growth potential and if they are successful, an exponential growth rate. The main characteristics of IDES and SMES are presented in table 1 (Aulet and Murray 2013). The distinction between these types of companies is the key to understanding the differences between companies and their potential for job creation and value added. Non-discrimination between entrepreneurs and their companies, which differ in innovation, ambitions, target markets and other characteristics, is impermissible, as it leads to a generalization of entrepreneurship. The distinction is particularly important in the light of developmental government policies that seek to promote long-term sustainable economic growth and development, and consequently social well being (Rebernik at al. 2016).

Numerous studies, especially global ones within the $\mathrm{OECD}$, as well as many at the country level, have shown that new enterprises are the driving force behind job creation (Calvino, Criscuolo, and Menon 2015). For example, Criscuolo, Gal, and Menon (2014) explored the growth dynamics of jobs in 17 OECD countries and Brazil, confirming the key role of newly created small businesses in job creation. Similarly, this was also confirmed by Haltiwanger, Jarmin, and Miranda (2013).

\section{Branding in Startups}

\section{IMPORTANCE OF BRANDING IN STARTUPS}

Strong brands are well accepted among their consumers, who have a unique and positive image of them (Keller 1993). The power of the brand occurs because these consumers have been exposed to clear business and marketing strategies implemented by the founders and other employees. These business and marketing strategies need to reflect the views of the founders and other employees in the startup. Internal stakeholders (founders, other employees) develop, co-create and live the brand, thus enabling external stakeholders (customers) to experience it. The previously described approach represents the main ideas of the so-called balanced or two dimensional perspective on branding (De Chernatony and McDonald 2001; Konecnik Ruzzier and Ruzzier 2009; Konecnik Ruzzier, Ruzzier, and Hisrich 2013) in a dynamic environment, and incorporates the idea of brand co-creation, where all stakeholders have a role in brand development (da Silveira, Lages, and Simões 2013).

The changing conditions in the market, more sophisticated and de- 
manding customers as well as a higher level of knowledge about branding strategies require a more systematic approach to branding than ever before. Branding plays an important role in SMEs (Krake 2005; Merrilees 2007; Spence and Essoussi 2010; Konecnik Ruzzier, Ruzzier, and Hisrich 2013), especially among those young companies that are innovative and have strong growth potential. As we highlighted earlier, the latter are called startups (Bresciani and Eppler 2010; Konecnik Ruzzier and Ruzzier 2015), where branding activities should be treated as strategic ones (Gardner and Cooper 2014; Busche 2014).

In the past, brand development models (i.e. De Chernatony 2010; Kapferer 1998; Aaker and Joachmisthaler 200o) were quite static, probably in line with changes, which accrued quite slowly. Da Silveira, Lages, and Simões (2013) seeks to advance the established conceptualization of brand identity by proposing brand identity as dynamic concept, constructed over time through mutually influencing inputs from managers and other stakeholder (e.g., consumers). Similarly, the startup branding funnel model, proposed by Ruzzier and Ruzzier (2015), represents a dynamic branding process that incorporates the current dynamics of the market, which is especially evident among startup companies. In its essence, the startup branding funnel model is the idea that the brand is an evolving entity (Ruzzier and Ruzzier 2015). This idea of a brand as an evolving entity was already stressed by previous authors (e.g. De Chernatony and Dall'Olmo Riley 1999; Burmann, Jost-Benz and Riley 2009; da Silveira, Lages, and Simões 2013; Gardner and Cooper 2014) in branding literature, while the idea of lean methodology (Ries 2011; Blank 2013) is presented mostly within entrepreneurship literature.

STARTUP BRANDING FUNNEL: DYNAMIC BRANDING PROCESS Ruzzier and Ruzzier (2015, 30-3) explain the branding process through four phases and eleven building blocks. The branding process starts with the vision, the building block zero, because it is the starting point of every entrepreneur's journey. In the first investigation phase, entrepreneurs need to investigate the industry, competitors, customers and key resources within the startup. During the second, development phase, the entrepreneurs start developing what Ruzzier and Ruzzier $(2015,71)$ indicate as the 'minimum viable brand,' which includes a story and visual elements. In the third, implementation phase, internal branding, marketing channels as well as communication strategy need to be developed. The last phase of validation and evaluation includes the process of brand 
validation and evaluation, which is done by the brand's customers but managed by the entrepreneurs. The validation and evaluation phase thus complements the first three phases, while some building blocks (like story, communication) can be validated with the help and feedback of customers. The last phase result in brand equity.

The startup branding funnel building blocks consist of (Ruzzier and Ruzzier 2015, 32):

- Building block zero: vision

- Context building blocks: industry, competitors, customers, myself

- Development building blocks: story, visual elements

- Implementation building blocks: internal branding, communication, channels

- Validation and evaluation building block: brand equity

'All new companies and new products begin with an almost mythological vision - a hope of what could be, with a goal few others can see' (Blank and Dorf 2012). A vision is a forward looking statement that sets the direction for the future development of a brand (De Chernatony 2010). As an example, take the Apple or Amazon brands and their leaders. We can describe Steve Jobs or Jeff Bezos with different superlatives in the process of their brand building, but what was probably the most important was their visionary role in brand development. Both had visions of what was to come.

Selecting the future industry of a startup is one of the first strategic decisions entrepreneurs need to make. The industry characteristics, specifics and potential significantly influence the success of a startup; therefore, its analysis and selection require considerable attention. The most important aspects related to the industry analysis are: estimated future industry growth; main trends; industry size; maturity of the industry; industry structure in terms of competition; entry barriers; capital intensity; and industry dynamics. The success of the startup brand is highly related to the target group of customers and the innovative way the startup addresses their perceived pains. In addition to knowing their target customers, the startups need to be aware of what others are doing in order to know how to develop, build, and strengthen their own brand. The focus should not only be on direct competitors who sell similar brands, but also indirect competitors who satisfy the same need of target customers with different brands. Knowing and understanding your competitors gives you the ability to position your brand uniquely in front 
of the competition. During the 'myself' building block, financial and human resources need to be evaluated (Ruzzier and Ruzzier 2015, 46).

Previously described context building blocks are all prerequisites for starting the development of a brand, starting with the brand story as the invisible part of the brand. In addition to brand vision, additional elements should be stressed: attributes, benefits, values, culture, personality, relationships and/or community. Attributes are those descriptive features that characterize a brand, such as what the consumer thinks the brand is or has and what is involved with its purchase or consumption. Benefits are personal values that consumers attach to the brand, namely what consumers think the brand can do for them (Keller 1993). A value is an enduring belief that a specific mode of conduct or end-state of existence is personally or socially preferable to an opposite or converse mode of conduct or end-state of existence (Rokeach 1973). Values provide guidance about a desired behavior. A set of agreed-upon brand values or principles can help employees to know how to behave in the company and consequently fulfill and deliver the brand's promises to target customers (De Chernatony 2010). Culture considers the way a brand can achieve a unique position through a particular type of staff behavior related to the brands' values, which characterize the organization's culture. Brand personality is described as a set of human characteristics associated with a brand (Aaker 1997). These human characteristics should be applicable to and relevant for brands. By using the metaphor of brand as personality, which can be manifested through a celebrity or people from ordinary life, customers find it easier to relate with and appreciate a brand (Ruzzier and Ruzzier 2015). The relationship between the customer and a brand helps the customer to better understand what the brand offers (De Chernatony 2010) and co-create the brand (Cova, Ford, and Salle 2009). Dynamic branding, in addition to the idea of listening to your customer, incorporates the idea of inviting customers to talk and to express their thinking about the brand (Busche 2014; Ruzzier and Ruzzier 2015). As dynamic branding evolves into brand-building relationships, brand communities are becoming common practice among startups, which are able to form and build communities even before the official launch of the brand (Ruzzier and Ruzzier 2015).

Visual elements include those elements that make the brand most visible and through which the consumers can better understand the brand. They often include elements such as name, symbol (logo, packaging), slogan and domain. When choosing the visual elements of a brand, Keller 
(1998) suggests that they should be: memorable, meaningful, likable in the eyes of target customers, transferable, adaptable and protectable, both from the legal and competitive point of view.

Spreading brand knowledge within the company is the main idea of internal branding, which can be achieved through internal communication, training and qualification (Miles and Mangold 2004; Terglav, Kaše, and Konecnik Ruzzier 2012). Burmann, Jost-Benz, and Riley (2009) argue, that only the integration of an internal perspective through the employee's attachment to the brand enables an accurate assessment of the entire brand. In startups, most activities are done very informally at the beginning, on a personal basis and as part of a special culture in the company. 'CEOs and co-founders are surely the best startup brand ambassadors, but they are not the only ones. Turning other members of the team into brand ambassadors is of great importance for the startup and its journey in brand building' (Ruzzier and Ruzzier 2015, 117). The rules of cost-effective marketing communications (Kotler and Keller 2012) particularly come to the forefront for startups. Ruzzier and Ruzzier (2015, 121) therefore proposed further marketing communication tools for startups: word-of-mouth marketing, interactive marketing, public relations, advertising, personal selling and direct marketing. The goal is to find the most suitable and cost-effective mix, which will result in marketing the brand in a more innovative and attractive way to target consumers as compared to its competitors. The basic task of marketing channels is to reach the target customers, either directly (direct marketing channel) and/or with the help of intermediaries (indirect marketing channel). Many startups use both approaches, while some start with one approach only (in many cases with direct marketing channels).

The validation and evaluation building block finally results in brand equity, as a concept of how customers perceived the brand. In general, a customer's evaluation of a brand can be measured with brand awareness, image, perceived quality and loyalty (Keller 1993; Konecnik Ruzzier and Gartner 2007). To the previous four elements, some authors add others, such as market share (Aaker 1996). Because startups need to have immediate feedback on their brand, these traditional measures should be upgraded and combined with other relevant key metrics (Croll and Yoskovitz 2013).

\section{Research Methodology}

Data were collected with the help of online survey. The questionnaire was addressed to founders or CEOs of legal and formally established 
young Slovenian innovative companies with a strong growth potential. The companies needed to be up to 6 years old. The study instrument can be divided into three parts in terms of content. The first part of the questionnaire contains entrepreneurial questions. In the second part of the questionnaire, marketing questions, with a specific focus on branding perspective, were posed. The third part of the questionnaire included characteristics of startup companies as well as sociodemographic characteristics of participants.

Branding questions, which are in the focus of this paper, were prepared according to previously analyzed literature, mainly according to the recently proposed startup branding funnel methodology (Konecnik Ruzzier and Ruzzier 2015). For each startup branding funnel building block (Konecnik Ruzzier and Ruzzier 2015), several statements were posed. Statements were measured on a 5-point Likert Scale anchored by 1 - strongly disagree to 5 - strongly agree.

\section{Results}

SAMPLE

The online mail survey resulted in 195 usable responses from Slovenian startups. Almost half of the interviewed startups (49.2\%) were under two years old, with $27.2 \%$ of them under one year and $22.1 \%$ under the age of two. $15.4 \%$ were under three years old and $11.8 \%$ younger than four years. The rest of them were younger than five or six years. Most, namely $41 \%$ of startups, had two co founders, $23.6 \%$ one founder and $19 \%$ had three co-founders. The rest of them were founded by four ( $9.2 \%)$, five $(5.1 \%)$ or even more co-founders.

Among 195 startups, $26.7 \%$ of them are in the so-called 'seed stage, where they are dealing with the challenges of developing and testing the concept of a product, and developing and testing a business model on the market, but not yet generating revenue. The next phase, i.e. the 'startup stage,' was the most numerous, as $41.5 \%$ of participating startups have already completed the development of their first selling product and are generating the first revenue. The third, so called 'growth stage,' consisted of $27.7 \%$ of startups, which in fact are already being transformed into established companies and leaving the status of a startup company. In the third group of startups, the market potential of the product and business model have been successfully validated on the market. At this stage, they are already ripe for an enhanced investment in market performance and the rapid growth of sales. $4.1 \%$ of startups did not identify the development stage in which they were currently. 
TA B LE 2 The Most Important Business Strategies

\begin{tabular}{lrr}
\hline Business strategy & M & SD \\
\hline Brand development & 4.16 & 0.969 \\
Product development & 4.11 & 1.034 \\
Organization development (processes, structure, communication ...) & 3.86 & 1.024 \\
Strengthening employees' motivation and their development & 3.70 & 1.164 \\
Fast growth & 3.61 & 1.127 \\
Strengthening the organizational culture (norms, standards, values ...) & 3.45 & 1.249 \\
Profitability & 3.36 & 1.114 \\
\hline
\end{tabular}

NOtes $M-$ mean, SD - standard deviation. $N=195$.

Startup companies are predominantly, but not exclusively, related to high technologies, so it is not surprising that as many as $17.4 \%$ of analyzed startups work in the field of industrial technology and hardware or software. Software development is followed by $10.8 \%$, software as a service model (SaaS) by $9.7 \%$ and $6.7 \%$ by green technologies. $5.6 \%$ of startups deal with online or mobile applications or solutions. It is clear from the data that significantly more than half of all startups work in IC T or IC T-related fields. An important share of $4.6 \%$ of the startups operate in the fields of bio- or nanotechnology and medical technologies, which are among the more demanding and promising sectors of the economy. The same percentage (4.6\%) of startups operate as consulting companies.

\section{STARTUP BRANDING FUNNEL BUILDING BLOCKS}

The various 'development' startup stages within the branding funnel require the entrepreneur to focus on some kind of business strategies or key activities. We asked respondents to evaluate the most important business strategy for their startup. Among all proposed business strategies (table $2)$, brand development was chosen as the most important one $(\mathrm{M}=4.16$, $\mathrm{SD}=0.969)$ and was closely followed by product development $(\mathrm{M}=4.11$, $\mathrm{SD}=1.034)$. In third place, the organization development was chosen $(\mathrm{M}$ $=3.86, \mathrm{SD}=1.024)$ and was followed by strategies for strengthening employee motivation and their development $(\mathrm{M}=3.7 \mathrm{O}, \mathrm{SD}=1.164)$. Due to the relatively small share of enterprises in the growth stage, it is quite understandable that fast-growing activities in the sample of surveyed startups are only in fifth place $(\mathrm{M}=3.61, \mathrm{SD}=1.127)$. The least important strategy for startups was profitability $(\mathrm{M}=3.36, \mathrm{SD}=1.114)$.

As can be seen from table 3, startup founders agreed that they had a 
TABLE 3 Vision Statements

\begin{tabular}{lrr}
\hline Building block o: Vision statements & M & SD \\
\hline When we founded the startup, we had a clear vision. & 3.93 & 1.008 \\
Throughout our business, our vision is being upgraded and cleaned. & 4.45 & 0.697 \\
\hline
\end{tabular}

NOtes $\mathrm{M}-$ mean, SD - standard deviation. $N=195$.

TABLE 4 Context Building Block Statements

\begin{tabular}{lrr}
\hline Context building blocks statements & M & SD \\
\hline We knew the industry we entered well. & 3.68 & 1.198 \\
At the time of entering the market, we did not have direct competition. & 3.03 & 1.416 \\
When we entered the market, we knew who our customers would be. & 3.83 & 0.978 \\
$\begin{array}{l}\text { Our customers today are different from those we anticipated when } \\
\text { entering the market. }\end{array}$ & 2.63 & 1.234 \\
$\begin{array}{l}\text { Our team covered diverse knowledge (tech., business, marketing, ...). } \\
\text { We outsource the lacking knowledge. }\end{array}$ & 4.22 & 0.872 \\
\hline
\end{tabular}

Notes $\mathrm{M}-$ mean, SD - standard deviation. $N=195$.

clear vision when they founded their startups $(\mathrm{M}=3.93, \mathrm{SD}=1.008)$ and even more so that their vison is being upgraded and cleaned throughout their business $(\mathrm{M}=4.45, \mathrm{SD}=0.697)$.

Among context building blocks statements (table 4), participants most agreed with the statement that their team covered diverse knowledge ( $\mathrm{M}$ $=4.22, \mathrm{SD}=0.872)$ and partly also that they outsource the knowledge they lack. As can be seen, the majority of startups agreed that they knew quite well who their customers would be $(\mathrm{M}=3.83, \mathrm{SD}=0.978)$ and the industry $(\mathrm{M}=3.68, \mathrm{SD}=1.198)$ when they entered the market. Participants had a diverse opinion about competition $(\mathrm{M}=3.03, \mathrm{SD}=1.416)$, also seen from the high standard deviation, as some thought that they had direct competitors, while others believed, that they didn't have any direct competition at the time of entering the market. Even less agreement and more diverse opinion is recognized in the customers they have today versus those they anticipated.

Participants strongly agreed that for market success, more than just a technically advanced product is needed $(M=4.76, \mathrm{SD}=0.555)$ as well as that they created a product with the help of their prospective users $(\mathrm{M}=$ $4.10, \mathrm{SD}=0.966)$. They understand the brand primarily as a good story $(\mathrm{M}=4.44, \mathrm{SD}=0.819)$ and not as visual elements $(\mathrm{M}=2.79, \mathrm{SD}=1.253)$. This was the only development building block statement (table 5) that had 
TABLE 5 Development Building Block Statements

\begin{tabular}{lrr}
\hline Development building blocks statements & M & SD \\
\hline $\begin{array}{l}\text { For market success, more than just a technically advanced product is } \\
\text { needed. }\end{array}$ & 4.76 & 0.555 \\
$\begin{array}{l}\text { We understand brand primarily as visual elements (name, logo, slogan, } \\
\text { domain, ...). }\end{array}$ & 2.79 & 1.253 \\
We also understand brand as a good story. & 4.44 & 0.819 \\
$\begin{array}{l}\text { Our story seems to be important and crucial to our success. } \\
\text { The values and culture we live contribute to our success. }\end{array}$ & 4.04 & 1.009 \\
We created a product (or service) with the help of our prospective users. & 4.10 & 0.966 \\
\hline
\end{tabular}

NOtes $\quad \mathrm{M}-$ mean, SD - standard deviation. $N=195$.

TABLE 6 Implementation Building Block Statements

\begin{tabular}{lrr}
\hline Implementation building blocks statements & $\mathrm{M}$ & $\mathrm{SD}$ \\
\hline We know how to fulfill our promise to our customers. & 4.29 & 0.725 \\
We carefully fulfill our promise to our customers. & 4.32 & 0.807 \\
Communication is an important part of our success. & 4.45 & 0.760 \\
$\begin{array}{l}\text { We adapt the communication according to the target group of cus- } \\
\text { tomers. }\end{array}$ & 4.36 & 0.802 \\
$\begin{array}{l}\text { Communities are important for our success. } \\
\text { Mostly we combine direct (our website) and indirect (through the }\end{array}$ & 4.02 & 1.030 \\
intermediaries) market channels. & 3.46 & 1.211 \\
\hline
\end{tabular}

NOTES M-mean, SD - standard deviation. $N=195$.

a mean value below 3 , while others were evaluated above 4 . Their brand story seems to be important and crucial to their success $(\mathrm{M}=4.04, \mathrm{SD}=$ 1.009), also with a combination of values and the culture that they live in the company $(\mathrm{M}=4.16, \mathrm{SD}=0.876)$.

Similarly, high agreement was recognized among implementation building block statements (table 6). Participants agreed, that they know how to fulfill their promise to their customers $(M=4.29, \mathrm{SD}=0.725)$ and that is important that they fulfill the promise carefully $(\mathrm{M}=4.32$, $\mathrm{SD}=0.807)$. Communication seems to be a very important part of their success $(\mathrm{M}=4.45, \mathrm{SD}=0.760)$, and they adapt it according to the target group of customers $(\mathrm{M}=4.36, \mathrm{SD}=0.802)$. It looks like communities are also important for their success $(\mathrm{M}=4.02, \mathrm{SD}=1.030)$. However, some startups combine direct and indirect markets channels, while others use only either the direct or the indirect approach to reach their customers. 


\section{Conclusion}

As can be seen from recent academic and practical literature, branding is also becoming an important topic among newly established companies that are entering today's hyper competitive market. This is especially evident in companies that are innovative and have high growth potential or so-called startup companies.

Our empirical research, conducted among 195 Slovenian startups, confirmed that branding is very important among newly established companies. Startup founders/CEos evaluated brand development as the most important business strategy in their startup, followed by product and organization development.

In addition to understanding the current circumstances on the market (industry, competitors) as well as target customers, startup founders and CEOS are convinced that more than just a technically advanced product is needed for market success. In addition, they understand brand primarily as a good story and not so much as visual elements. This understanding goes in line with modern brand conceptualization (De Chernatony 2010; Konecnik Ruzzier and Ruzzier 2013). In this regard, the brand story should originate from product or services uniqueness, but should be upgraded with emotional appeal, which invites potential customers to be not only buyers of a brand, but also its co-creators. Treating customers as co-creators was confirmed as an important issue in our research.

Startup founders/CEOS are convinced that correct and appropriate implementation is necessary for today's success on the market. Innovative and target oriented communication becomes a must for startups: it doesn't only raise awareness among their target customers but also consequently leads to the customers' emotional involvement, and hopefully ends with the purchase of a brand.

The above presented research findings guide many practical implications not only for startup companies, but also for other companies that operate in today's fierce competition. Today, we are witnessing many cases when larger or multinational companies are buying startups in order to gain new knowledge, including in the areas of brand development and its innovative marketing. In addition, brand building activities should be incorporated in the supporting activities on the policy level to support startup development not only in regards to development of innovative products, but also in support of other marketing and brand related activities. Firstly, good brand development and its maintenance on the market 
require a holistic approach toward brand building, where a unique and emotional brand story represents the core of brand building. Secondly, branding in startups is a dynamic activity that requires daily activities, but it should be also strategically driven with a clear focus on a long term vision. Thirdly, appropriate and up to date implementation of a brand is a must among companies. Understanding the brand inside the company, innovative, cost-efficient and targeted communication as well as the combination of appropriate market channels play an important role in brand development. Fourthly, potential target customers should not be treated only as buyers, but also as brand co-creators and its ambassadors.

The presented study is not free of limitations. As a new research topic, startup branding phenomena should be further investigated, from a theoretical as well as empirical point of view. More replications of the study are needed to confirm the importance of brand building activities of startups among other countries. We suggest also replications of the model on other companies, as model presents a dynamic approach to brand building. From the empirical point of view, additional statements should be added to separate funnel building blocks.

\section{References}

Aaker, D. A. 1996. Building Strong Brands. New York: The Free Press.

Aaker, J. L. 1997. 'Dimensions of Brand Personality'. Journal of Marketing 34 (3): $347-56$.

Aaker, D. A., and E. Joachimsthaler. 200o. Brand Leadership. New York: The Free Press.

Aulet, B., and F. Murray. 2013. A Tale of Two Entrepreneurs: Understanding Differences in the Types of Entrepreneurship in the Economy. Kansas City, мо: Ewing Marion Kauffman Foundation.

Blank, S. 2013. 'Why the Lean Start-Up Changes Everything.' Harvard Business Review 91 (5): 63-72.

Blank, S., and B. Dorf. 2012. The Startup Owner's Manual: The Step-by-Step Guide For Building a Great Company. Pescadero, CA: K\&s Ranch.

Bresciani, S., and M. J. Eppler. 2010. 'Brand New Ventures? Insights on Start-ups' Branding Practices.' Journal of Product \& Brand Management 19 (5): 356-66.

Burmann, C., M. Jost-Benz, and N. Riley. 2009. 'Towards an Identity-Based Brand Equity Model.' Journal of Business Research 62 (3): 390-97.

Busche, L. 2014. Lean Branding: Creating Dynamic Brands to Generate Conversion. Cambridge, ma: O’Reilly Media.

Calvino, F., C. Criscuolo, and C. Menon. 2015. 'Cross-Country Evidence on 
Start-Up Dynamics.' oECD Science, Technology and Industry Working Papers 2015/16, OECD, Paris.

Cova B., D. Ford, and R. Salle. 2009. 'Academic Brands and Their Impact on Scientific Endeavour: The Case of Business Research and Researchers.' Industrial Marketing Management 38 (6): 570-6.

Criscuolo, C., P. N. Gal, and C. Menon. 2014. 'The Dynamics of Employment Growth: New Evidence from 18 Countries.' oE CD Science, Technology and Industry Policy Papers 1274, OECD, Paris.

Croll, A., and B. Yoskovitz. 2013. Lean Analytics: Use Data to Build a Better Startup Faster. Cambridge, mA: O’Reilly.

Da Silveira, C., C. Lages, and C. Simoes. 2013. 'Reconceptualizing Brand Identity in a Dynamic Environment.' Journal of Business Research 66 (1): $28-36$.

De Chernatony, L. 2010. From Brand Vision to Brand Evaluation. Oxford: Butterworth-Heinemann.

De Chernatony, L., and M. McDonald. 2001. Creating Powerful Brands in Consumer, Service and Industrial Markets. Oxford: ButterworthHeinemann.

De Chernatony, L., and R. F. Dall'Olmo. 1999. 'Modelling the Components of the Brand.' European Journal of Marketing 32 (11-12): 1074-9o.

Gardner, J., and B. Cooper. 2014. Entrepreneur's Guide to the Lean Brand: How Brand Innovation Builds Passion, Transforms Organizations and Creates Value. San Diego CA: Market by Numbers.

Haltiwanger, J., R. Jarmin, and J. Miranda. 2012. Where Have all the Young Firms Gone? Kansas City, mo: Kauffman Foundation.

Kapferer, J. N. 1998. Strategic Brand Management. London: Kogan Page.

Keller, K. L. 1993. 'Conceptualizing, Measuring, and Managing CustomerBased Brand Equity.' Journal of Marketing 57:1-22.

- 1998. Strategic Brand Management: Building, Measuring, and Managing Brand Equity. London: Prentice-Hall.

Kotler, P., and K. L. Keller. 2012. Marketing Management. 12th ed. Upper Saddle River, NJ: Pearson Prentice Hall.

Konecnik Ruzzier, M., and W. C. Gartner. 2007. 'Customer-Based Brand Equity for a Destination.' Annals of Tourism Research 34 (2): 400-21.

Konecnik Ruzzier, M., and M. Ruzzier. 2009. 'A Two-Dimensional Approach to Branding: Integrating Identity and Equity.' In Tourism Branding: Communities in Action, edited by L. A. Cai, W. C. Gartner, and A. M. Munar, 65-73. Bingley, u K: Emerald.

- 2013. 'A Modern Approach to Brand Conceptualisation.' Transformations in Business and Economics 12 (3): 121-34.

— 2015. 'Startup Branding Funnel: A New Approach for Developing Startup Brands. Paper presented at the 4th Annual International Con- 
ference on Enterprise Marketing and Globalization and 5th Annual International Conference on Innovation and Entrepreneurship, Singapore, 14-15 December.

Konecnik Ruzzier, M., M. Ruzzier, and R. D. Hisrich. 2013. Marketing for Entrepreneurs and SMES: A Global Perspective. Cheltenham: Edward Elgar.

Krake, F. B. 2005. 'Successful Brand Management in smes: A New Theory and Practical Hints.' Journal of Product and Brand Management 14 (4): 228-38.

Merrilees, B. 2007. 'A Theory of Brand-Led sme New Venture Development.' Qualitative Market Research 10 (4): 403-15.

Miles, S. J., and G. Mangold. 2004. 'A Conceptualization of the Employee Branding Process.' Journal of Relationship Marketing 3 (2-3): 65-87.

Rebernik, M., K. Crnogaj, K. Širec, B. Bradač Hojnik, M. Rus, and P. Tominc. 2016. Dinamika podjetniškega potenciala: GEM Slovenija 2016. Maribor: Univerzitetna založba.

Ries, E. 2011. The Lean Startup: How Constant Innovation Creates Radically Successful Businesses. London: Penguin.

Rode, V., and C. Vallaster. 2005. 'Corporate Branding for Start-Ups: The Crucial Role of Entrepreneurs.' Corporate Reputation Review 8 (2): 12135 .

Rokeach, M. 1973. The Nature of Human Values. New York: Free Press.

Rus, M., and M. Rebernik. 2015. 'Izgrajevanje startup ekosistema v Sloveniji.' In Entrepreneurial Society: Current Trends and Future Prospects in Entrepreneurship, Organization and Management, edited by K. Vuković, R. Brčić, and M. Klačmer Čalopa, 287-92. Varaždin: Faculty of Organization and Informatics.

Spence, M., and L. H. Essoussi. 2010. 'sme Brand Building and Management: An Exploratory Study.' European Journal of Marketing 44 (7): 1037-54.

Terglav, K., R. Kaše, and M. Konečnik Ruzzier. 2012. 'Uresničevanje notranjega brandinga: Razvoj konceptualnega modela.' Management 7 (4): 309-29.

Timmons, J. A. 1999. New Venture Creation: Entrepreneurship for the 21st Century. Homewood, IL: Irwin.

Weiblen, T., and H. W. Chesbrough. 2015. 'Engaging with Startups to Enhance Corporate Innovation.' California Management Review 57 (2): 66-90.

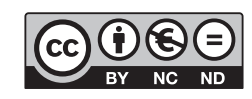

This paper is published under the terms of the Attribution-

NonCommercial-NoDerivatives 4.o International (CC B Y-NC-ND 4.0)

License (http://creativecommons.org/licenses/by-nc-nd/4.o/). 